\title{
Valuasi ekonomi dan pengelolaan mangrove secara berkelanjutan di desa Jangkang Kecamatan Bantan
}

\author{
Rizal Muhtady ${ }^{1}$, Thamrin ${ }^{2}$, Darwis ${ }^{3}$ \\ ${ }^{1,2}$ Program Studi Magister Ilmu Lingkungan Pascasarjana Universitas Riau \\ ${ }^{3}$ Fakultas Perikanan dan Kelautan Universitas Riau
}

\begin{abstract}
This study aims to determine the direct economic valuation, index value and sustainability status, and strategy for the sustainability of the mangrove ecosystem in Jangkang Village. The research method of calculating direct economic valuation is carried out using a market approach. To assess the index and status of sustainability with a multidimensional scaling (MDS) approach through the ordination technique Rapid Appraisal For Status Of Mangrove (Rap-Mangrove). The results showed that in direct economic valuation, the shrimp fishing sector has a greater potential compared to other sectors. The total economic value of shrimp is IDR 1,440,000,000 / year, capture fisheries is IDR 686,400,000 / year and panglong charcoal IDR 447,500,000 / year. The multidimensional results of the index value and the status of the sustainability of the mangrove ecosystem in Jangkang Village obtained a value of 50.76 in the less sustainable category. The results of the analysis leverage show that of the 18 indicators, there are 10 sensitive indicators that affect the sustainability status of Jangkang Village. To increase the sustainability status of sensitive indicators, strategies that can be carried out include participatory rehabilitation, development of alternative livelihoods, counseling for the Akit Tribe to maintain local wisdom values, and intensive approaches to community leaders.
\end{abstract}

Keywords: Mangrove; Economic Valuation; Sustainability

Wilayah pesisir laut Indonesia kaya akan sumberdaya. Ekosistem pesisir laut merupakan sumber daya alam yang produktif sebagai penyedia energi bagi kehidupan komunitas di dalamnya. Komponenkomponen yang menyusun ekosistem pesisir laut tersebut perlu dijaga dan dilestarikan karena menyimpan sumber keanekaragaman hayati dan plasma nutfah. Salah satu komponen ekosistem pesisir dan laut adalah hutan mangrove.

Desa Jangkang merupakan salah satu desa yang ada di Pulau Bengkalis tepatnya di Kecamatan Bantan Kabupaten Bengkalis Provinsi Riau. Letak geografis Desa Jangkang merupakan wilayah dengan tipologi desa pesisir. Dalam memenuhi kebutuhan hidup, masyarakat pesisir yang tinggal di wilayah ini menggantungkan hidup akan hasil laut yang bekerja sebagai nelayan. Desa Jangkang juga memiliki sumber daya alam khas pesisir pada umumnya yakni, mangrove. Pemanfaatan mangrove diperuntukkan untuk kegiatan perumahan dan kebutuhan rumah tangga. Namun dalam pemanfaatannya, tidak memperhatikan aspek keberlanjutan seperti eksploitasi berlebihan. Kondisi tersebut lama-kelamaan bisa menyebabkan menurunnya fungsi ekologi dan jasa lingkungan dari ekosistem mangrove. Dampak ekologi, degradasi mangrove menyebabkan akan terjadinya peningkatan abrasi yang sewaktu-waktu bisa mengancam keberlangsungan hidup terutama manusia yang tinggal diwilayah itu. Kejadian abrasi menjadi salah satu masalah yang belum dapat diatasi dengan baik di Pulau Bengkalis terutama beberapa desa di Kecamatan Bantan yang langsung berhadapan dengan perairan Selat Malaka. Desa Jangkang merupakan salah satu desa yang terparah dihantam abrasi. Dari segi ekonomi, degradasi mangrove telah menyebabkan berkurangnya hasil tangkapan ikan yang pada akhirnya berpengaruh menurunnya pendapatan nelayan setempat. Jika keadaan ini terus berlanjut, dampak sosial yang lebih jauh akan terjadinya peningkatan angka kemiskinan terutama pada nelayan yang masih dalam kategori warga prasejahtera .

Pemerintah daerah sudah seharusnya meningkatkan peran dalam upaya memelihara, memperbaiki dan menjaga agar mangrove tetap berkelanjutan. Selama ini, Pemda Bengkalis bersama masyarakat telah berupaya mengurangi resiko terjadinya degradasi hutan mangrove dengan melakukan beberapa kegiatan, diantaranya: rehabilitasi kembali mangrove yang telah rusak dan upaya sosialisasi terhadap masyarakat. Namun, upaya yang dilakukan selama ini belum membuahkan hasil yang efektif.

Oleh karena itu, perlu adanya suatu konsep dalam pengelolaan hutan mangrove yang bisa menjamin akan keberlangsungan hutan mangrove. Sehingga, generasi mendatang juga bisa menikmati manfaat dan jasa lingkungan hutan mangrove yang sangat besar ini. Mengacu UU No. 32 Tahun 2009 tentang perlindungan dan pengelolaan lingkungan hidup, dalam pengelolaan hutan perlu adanya upaya keberlanjutan. Konsep dalam pengelolaan mangrove secara berkelanjutan bertujuan bagaimana sumber 


\section{ZONA}

Jurnal Lingkungan

Volume 3, No 1, April 2019, p. 34-44

ISSN : 2502-6496 (Print)

http://zona.pelantarpress.co.id

daya mangrove yang ada bisa meningkatkan kesejahteraan dan taraf ekonomi masyarakat yang lebih baik sejalan dengan tetap memperhatikan aspek kelestarian lingkungan. Keberlanjutan pengelolaan mangrove memperhatikan beberapa dimensi seperti dimensi ekologi, dimensi ekonomi, dimensi sosial dan hukum/kelembagaan. Berdasarkan dimensi ekologi, pengelolaan mangrove diperlukan untuk rehabilitasi dan konservasi serta pembatasan pemanfaatan. Pengelolaan dimensi ekonomi lebih ditekankan bagaimana keberadaan mangrove bisa meningkatkan kesejahteraan masyarakat serta meningkatkan pendapatan bagi pemerintah daerah setempat. Pengelolaan dimensi sosial lebih ditekankan peningkatan akses masyarakat terhadap mangrove secara berkeadilan dan merata. Sedangkan pengelolaan dimensi secara kelembagaan dilakukan untuk penguatan kelembagaan melalui aturan pengelolaan. Keberlanjutan pengelolaan mangrove perlu juga didukung penilaian valuasi ekonomi langsung yang berguna menggambarkan nilai dari manfaat langsung yang dirasakan oleh masyarakat untuk memenuhi kebutuhan ekonomi dari keberadaan mangrove seperti penangkapan ikan atau pengambilan kayu mangrove. Penelitian-penelitian ilmiah tentang valuasi ekonomi dan pengelolaan keberlanjutan mangrove perlu untuk dilakukan. Mengingat, ekosistem mangrove merupakan sumberdaya yang sangat penting bagi keberlangsungan hidup masyarakat maupun makhluk hidup lainnya yang tinggal di wilayah pesisir Bengkalis

Penelitian ini bertujuan untuk mengetahui valuasi ekonomi langsung, nilai indeks dan status keberlanjutan, dan strategi keberlanjutan ekosistem mangrove Desa Jangkang.

\section{METODA PENELITIAN}

Penelitian ini dilaksanakan pada bulan Oktober-Desember 2018 di Desa Jangkang Kecamatan Bantan Kabupaten Bengkalis. Penentuan lokasi penelitian berdasarkan survei awal dengan pertimbangan: (1) Keberadaan mangrove berkaitan erat dengan produksi perikanan. Rusaknya mangrove akan berkurangnya produksi perikanan dan pada akhirnya berdampak pula pada perekonomian nelayan. (2) Adanya aktivitas pemanfaatan mangrove (3) Adanya kejadian abrasi di wilayah tersebut. Alat dan bahan pada penelitian ini terdiri dari: (1) Alat; seperangkat komputer untuk menginput data, software RapMangrove untuk menganalisis keberlanjutan hutan mangrove, kamera digital untuk dokumentasi objek, GPS untuk menentukan titik koordinat penelitian dan alat tulis untuk mencatat hasil observasi. (2) Lembar kuesioner saat wawancara, peta wilayah, dan buku identifikasi mangrove untuk mengetahui jenis mangrove, satwa dan tumbuh-tumbuhan.

Pendekatan yang digunakan dalam penelitian ini adalah pendekatan kuantitatif dengan menggunakan metode survei. Sumber data pada penelitian terdiri dari data primer dan data sekunder. Sumber data primer didapatkan langsung dilokasi penelitian seperti: komoditi perikanan dan kayu yang ada dikawasan hutan mangrove. Untuk mendapatkan data primer juga dilakukan wawancara pada masyarakat pemanfaat mangrove, informan dan observasi langsung ke lapangan.

Sumber data sekunder didapatkan dari penelusuran dokumen (studi literatur) instansi yang terkait dengan wilayah penelitian, statistik kecamatan/desa, data dari penelitian sebelumnya dan data pendukung lainnya. Data sekunder yang dibutuhkan seperti: Data pemanfaat mangrove, potensi perekonomian sektor perikanan. Teknik pengumpulan data dengan observasi,wawancara dan kajian dokumen. Populasi adalah keseluruhan masyarakat pemanfaat mangrove seperti; (nelayan menangkap ikan 22 orang, nelayang udang 40 orang, panglong arang 18 orang) dan responden pakar berjumlah 10 orang.

Analisis data pada penelitian ini dilakukan untuk menghitung valuasi ekonomi langsung dan nilai indeks dan status keberlanjutan mangrove. Valuasi ekonomi langsung dilakukan dengan pendekatan pasar. Analisis nilai indek dan status keberlanjutan dengan metode Rap-Mangrove berbasis multidimensional scaling (MDS). Hasil nilai indeks keberlanjutan disajikan dalam bentuk skala rentang $0 \%$ samapai $100 \%$ yang terbagi kedalam 4 kategori; 0-25 tidak berkelanjutan, 26-50 kurang berkelanjutan, 51-75 cukup berkelanjutan, 76-100 berkelanjutan (Fauzi dan Anna,2005).

Tahapan dalam analisis keberlanjutan dengan metode Rap-Mangrove menjadi tiga tahapan, yaitu: (1) penentuan indikator didapatkan observasi langsung maupun data sekunder dari penelitian terkait; (2) penilaian indikator pada setiap indikator melalui kuesioner penelitian; (3) penilaian indeks dan status keberlanjutan secara multidimensional scaling (MDS), analisis sensitif indikator, dan analisis monte carlo. 


\section{HASIL DAN PEMBAHASAN}

\section{Valuasi Ekonomi Mangrove Desa Jangkang}

Berdasarkan hasil pengamatan dan wawancara dengan masyarakat setempat, nilai ekonomi langsung dari eksistensi mangrove di Desa Jangkang antara lain: perikanan tangkap, udang dan kayu mangrove untuk panglong arang.

\section{Perikanan Tangkap}

Ekosistem mangrove memberikan manfaat besar bagi sumber daya perikanan. Sekitar $30 \%$, produksi perikanan dipengaruhi akan keberadaan mangrove (Rangkuti, 2017). Sumber daya perikanan merupakan salah satu sektor penghasil dan penyumbang pendapatan terbesar di daerah Bengkalis. Data dari Dinas Perikanan dan Kelautan Kabupaten Bengkalis Tahun 2015, Kecamatan Bantan merupakan sentra produksi perikanan tangkap terbesar kedua setelah Kecamatan Rupat Utara dengan jumlah 1.670 Ton/Tahun.

Desa Jangkang merupakan salah satu desa yang berada di Kecamatan Bantan yang memilki sumber daya perikanan yang melimpah. Jenis perikanan tangkap pada umumnya: ikan terubuk, kurau, malong, gerut, debuk, talang, kelampai. Sistem penjualan yang dilakukan dengan penjualan langsung ditempat pelelangan ikan dan pada toke yang telah memesan untuk dijual kembali di pasar ikan. Jumlah nelayan penangkap ikan yang aktif melaut sebanyak 22 orang. Adapun estimasi keseluruhan nilai ekonomi nelayan ikan tangkap dapat dilihat pada Tabel 1.

Tabel 1. Nilai Ekonomi Ikan Tangkap Desa Jangkang

\begin{tabular}{clc}
\hline No & Uraian & Nilai \\
\hline 1 & Jumlah nelayan (orang) & 22 \\
2 & Jumlah trip penangkapan (nelayan/tahun) & 240 \\
3 & Harga ikan rata-rata per kg (Rp) & 35.000 \\
4 & Produksi ikan (kg/tahun/nelayan) & 1.440 \\
5 & Biaya operasional (nelayan/hari) & 80.000 \\
\hline
\end{tabular}

Nilai ekonomi ikan per nelayan/tahun

Rp 31.200.000

Dari tabel diatas dapat disimpulkan, nilai tangkapan ikan Desa Jangkang per nelayan dalam 1 tahun adalah $\mathrm{Rp}$ 31.200.000. Di Desa Jangkang, jumlah nelayan tangkap ikan sebanyak 22 nelayan. Jadi, total keseluruhan nilai ekonomi ikan tangkap di Desa Jangkang adalah Rp 686.400.000.

\section{Penangkapan Udang}

Udang memiliki keterkaitan erat dengan mangrove. Secara biologis, fungsi mangrove sebagai tempat mencari makan, pembesaran dan berlindung bagi udang. Bisa dikatakan, keberadaan udang tergantung akan kelestarian mangrove. Penelitian (Osmaleli, 2014) menunjukkan, penambahan setiap luas mangrove per $1 \mathrm{~km}$ akan berdampak pada peningkatan produksi udang sebesar 0,0015 ton. Namun sebaliknya jika terjadi peningkatan alih fungsi lahan ekosistem mangrove untuk lahan budidaya (Tambak), pemukiman atau sebagai wilayah industri akan berdampak negatif pada ketersediaan udang dengan penurunan produksi udang sebesar 0,0015 ton dan akan berdampak pada pendapatan nelayan.

Di Desa Jangkang, Udang merupakan hasil tangkapan lain selain ikan dengan potensi yang cukup besar. Hasil wawancara, jumlah nelayan udang yang masih aktif melaut sebanyak 40 orang. Alat tangkap yang digunakan terdiri dari jaring udang untuk armada penangkapan kapal dan langgai untuk nelayan 
pejalan kaki. Jenis-jenis udang hasil tangkapan diantaranya: udang gogo, belang merah, kibi. Adapun estimasi nilai ekonomi total dari udang per tahun dapat dilihat pada Tabel 2.

Tabel 2. Nilai Ekonomi Penangkapan Udang Desa Jangkang

\begin{tabular}{clc}
\hline No & Uraian & Nilai \\
\hline 1 & Jumlah nelayan (orang) & 40 \\
2 & Jumlah trip penangkapan (nelayan/tahun) & 240 \\
& & 50.000 \\
3 & Harga udang rata-rata per kg (Rp) & 960 \\
4 & Produksi udang (kg/tahun/nelayan) & 50.000 \\
5 & Biaya operasional (nelayan/hari) & $\mathrm{Rp} \mathrm{36.000.000}$ \\
\hline
\end{tabular}

Dari tabel diatas dapat dilihat, nilai tangkapan udang Desa Jangkang per nelayan dalam 1 tahun adalah Rp 36.000.000. Di Desa Jangkang, jumlah nelayan tangkap udang sebanyak 40 nelayan. Jadi, total keseluruhan nilai ekonomi udang di Desa Jangkang adalah $\mathrm{Rp}$ 1.440.000.000.

\section{Kayu Mangrove untuk Panglong Arang}

Mangrove yang masih banyak tumbuh di Desa Jangkang berada di tepat sepanjang aliran sungai. Keberadaan mangrove disekitar aliran sungai dimanfaatkan masyarakat yang tinggal di wilayah itu. Pada umumnya, mangrove yang ada dijadikan untuk kebutuhan panglong arang. Pemanfaat kayu mangrove untuk panglong arang sebagian besar adalah masyarakat suku akit (peranakan suku asli dan cina) yang telah mendiami cukup lama dari generasi terdahulu. Menurut (Susilo dalam Miswadi, 2017) kehidupan masyarakat yang dekat dengan ekosistem mangrove, mendorong masyarakat tempatan untuk memanfaatakan mangrove yang ada. Faktor lain, sulitnya mencari pekerjaan dan rendahnya tingkat pendidikan, bekerja sebagai pembuat panglong merupakan profesi yang bisa diandalkan. Aktivitas lain untuk mencukupi kebutuhan hidup mereka, masyarakat suku akit memanfaatkan tanaman perkarangan seperti kelapa, pinang, sayuran, buah-buahan untuk dikonsumsi sendiri dan diperjualbelikan.

Berdasarkan hasil wawancara dengan tokoh masyarakat Suku Akit (Pak Iban), banyaknya dapur arang yang masih aktif beroperasi hingga saat ini berjumlah 26 unit yang terdiri dari dapur arang berukuran besar 15 unit dan berukuran kecil sebanyak 11 unit. Lamanya produksi arang dilakukan kurang lebih selama 20 hari. Adapun tahapan produksi dimulai dengan pengambilan kayu disepanjang aliran sungai. Waktu pengambilan kayu dimulai dari pagi menjelang siang. Penebangan kayu dilakukan dengan peralatan seperti parang, kapak dan chain shaw. Jenis kayu yang ditebang sebagai bahan baku arang adalah jenis kayu bakau (Rhizophora apiculata) yang memiliki ukuran diameter batang $4-10 \mathrm{~cm}$, panjang rata-rata $280 \mathrm{~cm}$ dan berat rata-rata $20 \mathrm{~kg}$. Jenis Rhizophora apiculata adalah jenis kayu yang mudah terbakar dan cocok dijadikan arang. Sesuai dengan penelitian (Tumisem, 2008), bahwa kayu dengan kepadatan yang tinggi akan menjadi lebih berat (rata-rata $0,9 \mathrm{~m} / \mathrm{s}$ ), keras, mempunyai daya keawaten yang lama dan merupakan bahan bakar yang baik dengan panas yang ditimbulkan cukup tinggi serta nyala apinya cukup lama.

Sistem pemasaran panglong arang dijual ke toke. Selain untuk kebutuhan di pasar lokal area Bengkalis, panglong arang juga diekspor ke negara tetangga seperti Malaysia, Thailand, Singapura. Sesuai dengan penelitian (Indriani dalam Miswadi, 2017), kayu arang dari produksi masyarakat di Pulau Bengkalis dipasarkan ke negara tetangga yaitu Malaysia dan Singapura. Permintaan untuk pasar luar negeri, menurut pekerja panglong biasanya digunakan untuk kebutuhan rumah/restoran. Adapun rincian estimasi nilai ekonomi panglong arang pada Tabel 3. dibawah ini adalah 
Tabel 3. Nilai Ekonomi Panglong Arang

\begin{tabular}{|c|c|c|c|}
\hline \multirow[t]{2}{*}{ No } & \multirow[t]{2}{*}{ Uraian } & \multicolumn{2}{|c|}{ Nilai } \\
\hline & & Dapur Besar & Dapur Kecil \\
\hline 1 & Jumlah Dapur Arang & 15 & 11 \\
\hline 2 & Rata-rata siklus pembakaran dalam 1 tahun & $10 \mathrm{x}$ & $10 \mathrm{x}$ \\
\hline 3 & Harga jual arang (Rp/kg) & 2.500 & 2.500 \\
\hline 4 & $\begin{array}{l}\text { Rata-rata nilai produksi arang } / \mathrm{kg} / \text { siklus } \\
\text { pembakaran }\end{array}$ & 1.500 & 800 \\
\hline 5 & Biaya operasional /siklus pembakaran & 1.500 .000 & 1.000 .000 \\
\hline \multirow[t]{2}{*}{6} & Nilai ekonomi dalam 1 tahun & 337.500 .000 & 110.000 .000 \\
\hline & Total Keseluruhan Nilai Panglong/tahun & \multicolumn{2}{|c|}{$\mathrm{Rp} 447.500 .000$} \\
\hline
\end{tabular}

\section{Nilai Indeks dan Status Keberlanjutan Pengelolaan Ekosistem Mangrove Di Desa Jangkang}

Seluruh indikator pada penelitian ini berjumlah 18 indikator yang terdiri atas 4 indikator dimensi ekologi, 4 indikator dimensi ekonomi, 5 indikator dimensi sosial dan 5 indikator untuk dimensi kelembagaan. Hasil yang diperoleh menunjukkan (Gambar 1), nilai rata-rata indeks keberlanjutan multidimensi adalah 50.76 atau berada pada selang 26-50 dan dikategorikan kurang berkelanjutan. Besaran nilai pada setiap dimensi yaitu; dimensi ekologi 32.71 (kurang berkelanjutan), dimensi ekonomi 64.69 (cukup berkelanjutan), dimensi sosial 52.83 (cukup berkelanjutan), dan dimensi kelembagaan 52.83 (cukup berkelanjutan).

Pada setiap dimensi memperlihatkan bahwa, diantara empat dimensi yang ada ternyata dimensi ekologi merupakan dimensi yang paling buruk status keberlanjutannya.

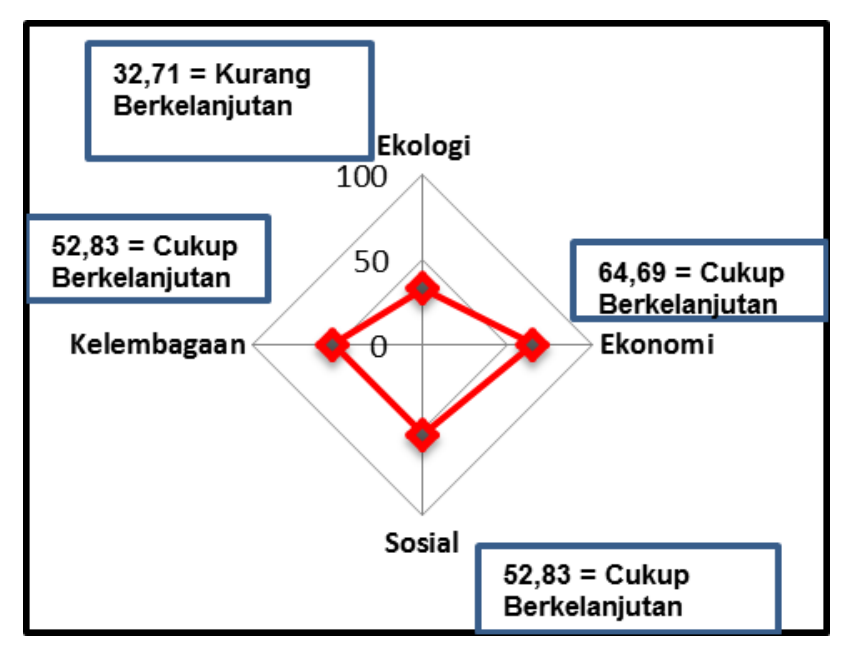

Gambar 1. Diagram Layang Multidimensi

Parameter statistik yang digunakan untuk menentukan kelayakan terhadap hasil penilaian yang telah dilakukan adalah nilai stress dan koefesien determinasi $\left(\mathrm{R}^{2}\right)$. Nilai strees dan koefesien determinasi dari masing-masing dimensi dapat dilihat pada Tabel 4. 
Tabel 4. Nilai Statistik Hasil Analisis Rap-Mangrove Pada Masing-Masing Dimensi

\begin{tabular}{lllll}
\hline Nilai Statistik & Ekologi & Ekonomi & Sosial & Kelembagaan \\
\hline Stress & $16.70 \%$ & $15.48 \%$ & $15.53 \%$ & $15.53 \%$ \\
$\mathrm{r}^{2}$ & $93 \%$ & $92 \%$ & $93 \%$ & $93 \%$ \\
\hline
\end{tabular}

Menurut (Kavanagh dalam Yulinda, 2018) Nilai stress diperbolehkan apabila dibawah nilai 25\%. Berdasarkan tabel diatas, masing-masing dimensi memiliki nilai stress yang lebih kecil yaitu dibawah $25 \%$. Artinya, nilai tersebut sudah memenuhi kondisi yang cukup baik. Karena semakin kecil nilai stress yang didapat menunjukkan semakin baik kualitas hasil analisis. Sedangkan untuk nilai koefisien determinasi $\left(\mathrm{R}^{2}\right)$ tergolong baik apabila berada pada rentang $80 \%$ sampai $100 \%$. Nilai keofesien determinasi dari masing-masing diatas menunjukkan berada pada nilai 92\%-93\%. Dengan demikian kedua parameter (nilai stress dan $\mathrm{R}^{2}$ ) menunjukkan bahwa seluruh indikator yang digunakan pada analisis ini cukup baik untuk menerangkan masing-masing dimensi tersebut.

Selanjutnya untuk menguji tingkat kepercayaan nilai indeks dilakukan dengan analisis monte carlo. Perbandingan indeks keberlanjutan hasil MDS dengan hasil analisis monte carlo dapaat dilihat pada Tabel 5.

Tabel 5. Hasil Perbandingan Indeks Keberlanjutan Hasil MDS dan Monte Carlo

\begin{tabular}{lllll}
\hline No & Dimensi & MDS & Monte Carlo & Perbedaan \\
\hline 1 & Ekologi & 32.71 & 32.93 & 0.22 \\
2 & Ekonomi & 64.69 & 63.10 & 1.59 \\
3 & Sosial & 52.83 & 52.30 & 0.53 \\
4 & Kelembagaan & 52.83 & 52.53 & 0.30 \\
\hline
\end{tabular}

Berdasarkan tabel diatas, menunjukkan bahwa nilai indeks keberlanjutan yang didapat pada setiap dimensi tidak banyak mengalami perbedaan, yakni kecil dari lima $(<5)$, dengan perbedaan pada dimensi ekologi sebesar 0.22 , dimensi ekonomi 1.59 , dimensi sosial 0.53 , dan dimensi kelembagaan 0.30 . Kecilnya perbedaan ini mengindikasikan bahwa (1) kesalahan dalam pembuatan skor pada setiap indikator relatif kecil, (2) ragam pemberian skor akibat perbedaan opini relatif kecil, (3) proses analisis yang dilakukan secara berulang stabil, dan (4) kesalahan pemasukkan data dan data yang hilang dapat dihindari. Dengan demikian diketahui bahwa analisis keberlanjutan yang dilakukan dengan teknik Rap-Mangrove untuk keberlanjutan mangrove Desa Jangkang memiliki tingkat kepercayaan yang tinggi.

\section{Indikator Sensitif Dimensi Ekologi}

Analisis leverage (Sensitivitas) menunjukkan terdapat 4 dimensi yang sensitif terhadap nilai indeks keberlanjutan pada dimensi ekologi, yaitu; (1) Tingkat keragaman hutan mangrove, (2) rehabilitasi mangrove, (3) tekanan lahan mangrove, dan (4) abrasi pantai

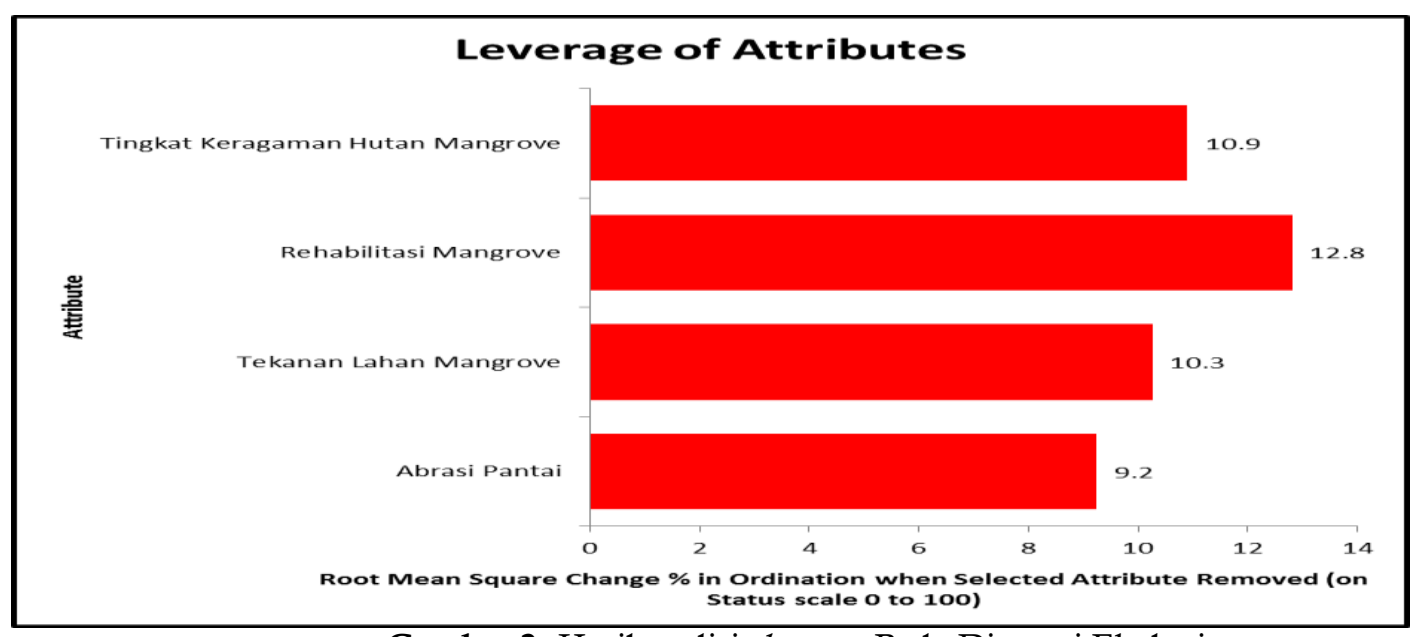

Gambar 2. Hasil analisis leverage Pada Dimensi Ekologi 
Hasil pengamatan dikawasan mangrove, keanekaragaman jenis mangrove yang masih tumbuh dikawasan aliran sungai Desa Jangkang sudah cukup beragam. Untuk keanekaragaman jenis mangrove, Menurut (Leksono dalam Heriyadi et.al, 2018) dapat diperbaiki dengan menambahkan jumlah jenis mangrove melalui program rehabilitasi.

Rehabilitasi merupakan upaya pemulihan mangrove yang telah rusak menjadi lebih stabil (Rusdianti dan Sunito 2012). Kegiatan rehabilitasi mangrove sudah dilakukan baik dari Pemda maupun kelompok pemerhati mangrove yang ada di Desa Jangkang. Namun keberhasilan rehabilitasi masih tergolong rendah. Untuk meningkatkan status keberlanjutan, indikator rehabilitasi mesti ditingkatkan dengan upaya peningkatan partisipasi masyarakat serta teknik rehabilitasi yang baik.

Tekanan lahan mangrove di Desa Jangkang terjadi karena adanya aktivitas pemanfaatan mangrove seperti; penebangan kayu untuk panglong arang. Hasil wawancara bersama masyarakat, akan adanya perluasan kawasan mangrove untuk dijadikan tambak. Penelitian (Handayani, 2016) menjelaskan jenis aktivitas penduduk yang lebih dominan dalam merusak ekosistem mangrove yaitu jenis konversi lahan (Pertambakan, pembangunan dan pemukiman). Untuk itu diperlukan upaya kesadaran bersama bagaimana pemanfaatan mangrove secara berkelanjutan kedepannya.

Kerusakan mangrove selalu diringi dengan permasalahan lingkungan, salah satunya kejadian abrasi. Dalam penelitian (Sutikno, 2014), dalam kurun waktu 26 tahun terakhir rata-rata laju abrasi yang terjadi di kawasan pesisir Pulau Bengkalis adalah sebesar 59 ha/tahun. Hal ini mengindikasikan berkurangnya luasan mangrove sebagai pelindung alami pantai yang mempercepat terjadinya abrasi di Pulau Bengkalis. Upaya menekan laju abrasi dengan membuat pemecah gelombang (Turap) selama ini belum cukup berhasil. Biaya yang cukup besar menjadi faktor penyebab upaya ini tidak berjalan efektif. Dibutuhkan alokasi anggaran yang besar baik yang bersumber dari APBN maupun Swasta.

\section{Indikator Sensitif Dimensi Ekonomi}

Hasil analisis leverage dari empat indikator pada dimensi ekonomi menunjukkan terdapat empat indikator yang berpengaruh terhadap nilai indeks keberlanjutan dimensi ekonomi, yaitu , (1) angggaran pemda untuk mangrove, (2) keuntungan pemanfaatan mangrove, (3) zonasi mangrove, dan (4) pemanfaatan mangrove merupakan indikator sensitif terhadap keberlanjutan.

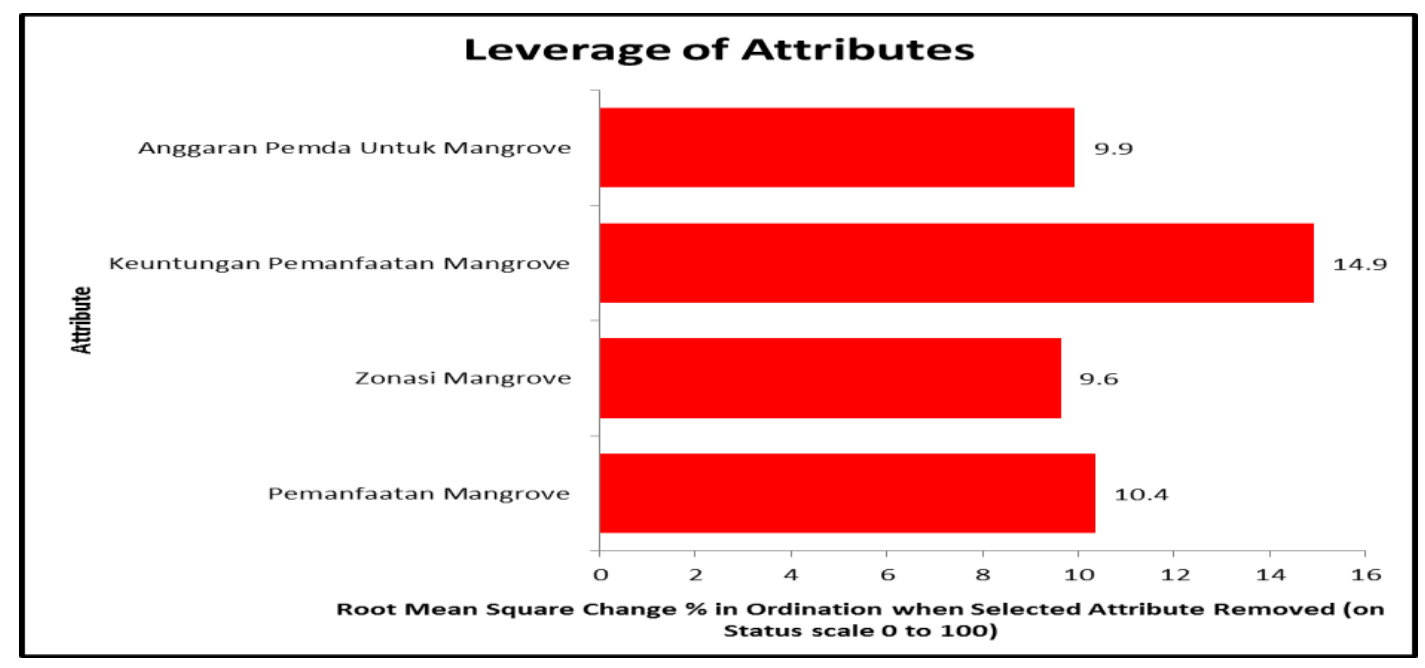

Gambar 3. Hasil Analisis leverage Dimensi Ekonomi

Alokasi anggaran untuk kegiatan pengelolaan mangrove masih belum tercapai kecukupan. Hal ini dikarenakan pelayanaan pengelolaan, koordinasi pengelolaan lintas sektor, sumber daya manusia belum optimal. Untuk itu meningkatkan keberlanjutan, perlu adanya perhatian khusus terkait alokasi anggaran penanganan Mangrove baik dana yang bersumber dari APBN/ABDP maupun swasta.

Keberadaan mangrove dirasakan memberikan keuntungan dalam mencukupi kebutuhan sehari-hari. Hal ini ditunjukkan dengan pemanfaatan langsung oleh masyarakat untuk mengambil hasil kayu dijadikan panglong yang sudah ditekuni cukup lama oleh masyarakat Suku Akit. Usaha panglong saat ini diperjualbelikan bahkan permintaan hingga ke negara tetangga seperti malaysia. Hasil penelitian (Rouf et 
al, 2019) disimpulkan bahwa keberadaan hutan mangrove berpengaruh langsung dalam mencukupi kebutuhan ekonomi masyarakat. Namun, jika pemanfaatannya tidak dalam kendali aturan maka akan berdampak meningkatnya kerusakan hutan mangrove.

Zonasi kawasan mangrove sangatlah penting untuk berbagai tujuan pengelolaan mangrove dan dalam rangka menghindari terjadinya konflik pemanfaatan lahan. Desa Jangkang saat ini belum tersedia zona pemanfaatan lahan mangrove. Untuk meningkatkan status keberlanjutan, zonasi perlu dilakukan untuk mengatur pemanfaataan dilokasi kawasan mangrove.

Pemanfaatan sumberdaya mangrove oleh masyarakat sangat tinggi. Hal ini ditandai tidak adanya akses pembatasan antara masyarakat dengan sumberdaya. Terbukanya akses menurut (Pattimahu, 2010), akan membuat masyarakat menyadari betapa pentingnya pengelolaan dan kelestarian sumberdaya alam yang ada. Namun disisi lain, terbukanya akses tanpa adanya aturan yang jelas mengatur pemanfaatannya dapat berdampak buruk. Sumberdaya hutan yang memiliki karakteristik sebagai sumberdaya milik bersama mempunyai kecenderungan rusak dari waktu ke waktu (Kustanti, 2013).

\section{Indikator Sensitif Dimensi Sosial}

Hasil analisis leverage pada dimensi sosial, dari lima indikator terdapat satu indikator yang berpengaruh terhadap nilai indeks keberlanjutan, yaitu kearifan lokal.

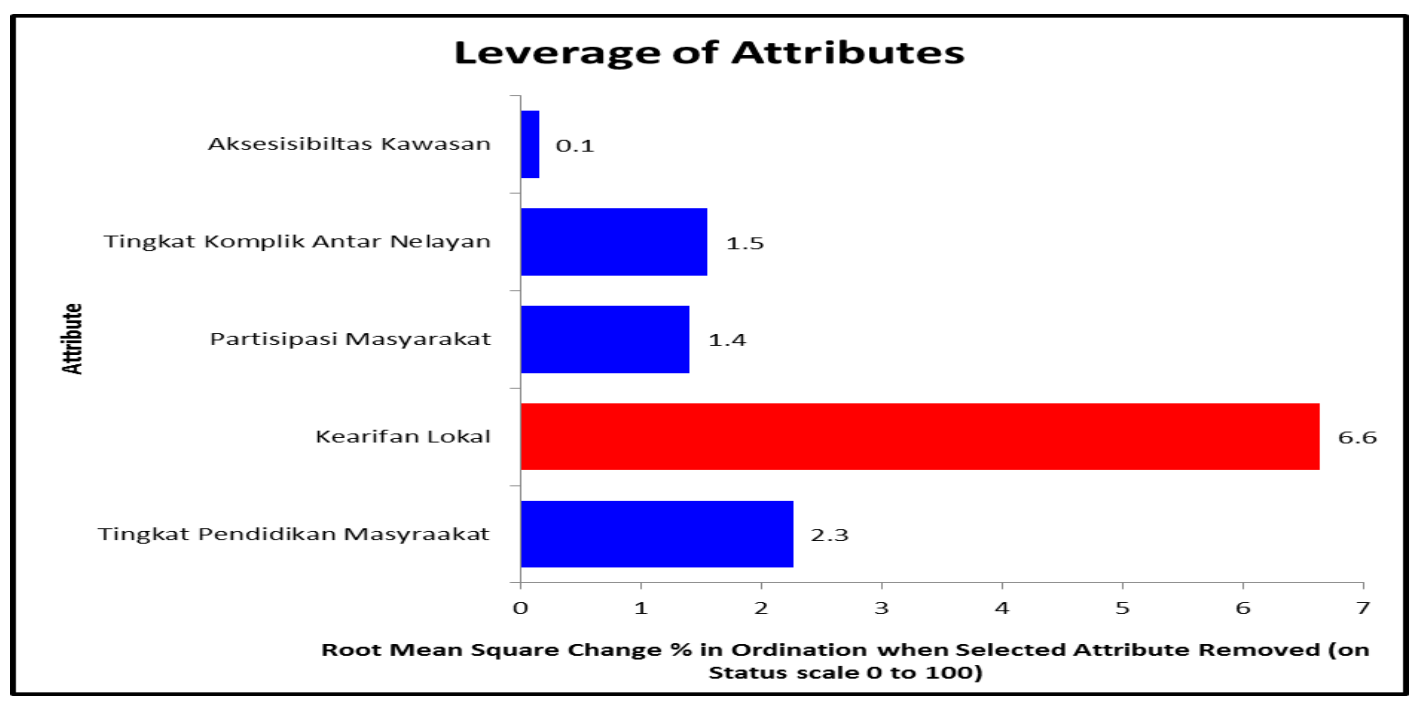

Gambar 4. Hasil analisis leverage Dimensi Sosial

Kearifan lokal merupakan indikator yang perlu mendapat perhatian terhadap keberlanjutan ekosistem mangrove. Masyarakat Suku Akit Desa Jangkang memiliki yang kebiasaan dan pengetahuan tersendiri dalam mengelola hutan mangrove. Dalam mengambil kayu, masyarakat Suku Akit hanya mengambil kayu yang berukuran besar dan tua yang sudah layak ditebang.

Menurut (Mufid, 2010), Kearifan lokal jika dipraktekkan dengan benar dan sunguh-sungguh, manfaat yang didapat dapat menuntun masyarakat lebih peduli dan tanggung jawab terhadap lingkungan Namun pada kenyataannya, keberadaan kearifan lokal belum sepenuhnya efektif karena masyarakat masih melakukan aktifitas yang sifatnya merusak. Beberapa faktor penyebabnya; kurangnya pekerjaan alternatif, meningkatnya jumlah penduduk diiringi dengan meningkatnya kebutuhan, masyarakat tidak memliki lahan lain untuk usaha sektor pertanian. Oleh karena itu indikator kearifan lokal dari masyarakat Suku Akit ini perlu menjadi perhatian yang melibatkan dari berbagai pihak agar nilai-nilai yang ada di masyarakat tidak hilang oleh zaman dan kebutuhannya.

\section{Indikator Sensitif Dimensi Kelembagaan}

Hasil analisis leverage, dari lima indikator terdapat satu indikator yang berpengaruh terhadap nilai indeks keberlanjutan pada dimensi kelembagaan, yaitu ketersediaan dan peran tokoh masyarakat. Indikator yang memberikan pengaruh pada dimensi kelembagaan adalah ketersediaan dan peran tokoh masyarakat. Tokoh masyarakat merupakan orang yang mempunyai pengaruh di masyarakat baik yang 
dipilih secara formal maupun normal. Peranan tokoh masyarakat sangat penting dalam mendukung keberlanjutan mangrove kedepannya.

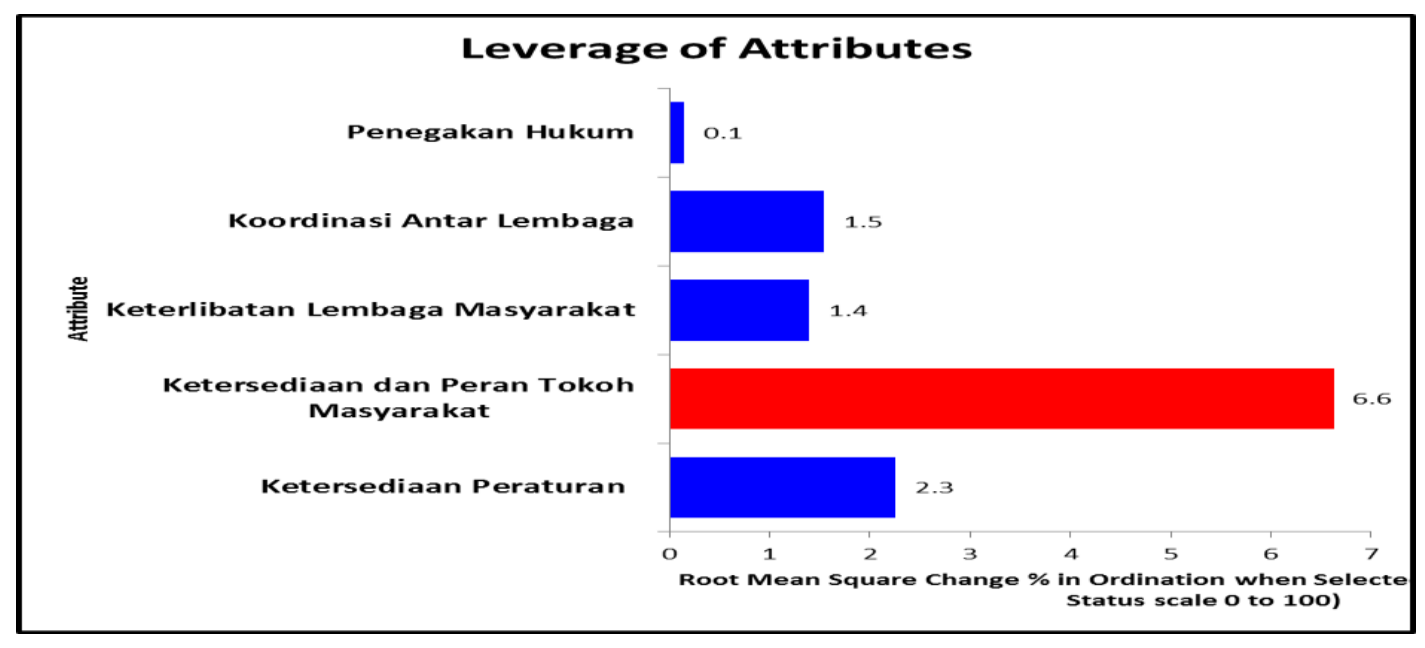

Gambar 5. Hasil analisis leverage Pada Dimensi Kelembagaan

\section{Strategi Pengelolaan Ekosistem Mangrove Secara Berkelanjutan Di Desa Jangkang}

Menurut (Susiolo dalam Noveliyana, 2016) nilai indikator sensitif dari masing-masing dimensi merupakan prioritas dalam pengambilan kebijakan pengelolaan mangrove kedepannya. Indikator yang memiliki kategori buruk mencerminkan kebijakan yang ada perlu menjadi perhatian untuk perbaikan

Berdasarkan indikator sensitif dari setiap dimensi, maka strategi kebijakan yang dapat dilakukan dalam upaya meningkatkan status keberlanjutan pengelolaan mangrove Desa Jangkang kedepannya antara lain:

\section{Dimensi Ekologi}

Dimensi ekologi dikategorikan dalam status kurang berkelanjutan. Untuk itu indikator yang berpengaruh seperti Abrasi pantai, tekanan lahan mangrove, rehabilitasi mangrove dan tingkat keragaman jenis mangrove akan menjadi fokus perhatian kedepannya.

Meningkatnya kejadian abrasi, tekanan terhadap mangrove dan upaya untuk keragaman jenis mangrove dapat dilakukan dengan meningkatkan kegiatan rehabilitasi. Rehabilitasi yang sifatnya partisipatif melibatkan seluruh masyarakat. Menurut (Rusdianti dan Sunito, 2012), kegiatan rehabilitasi membutuhkan pengawasan dan partisipasi penduduk lokal. Kenyataan selama ini, segala kegiatan yang berkaitan dengan pengelolaan mangrove masih belum mempertimbangkan keterlibatan masyarakat. Segala perencanaan dan pola pengelolaan cenderung bersifat dari atas ke bawah (top down). Selain itu, pengelolaan kawasan pesisir oleh pemerintah cenderung lebih menggunakan pendekatan pembangunan fisik seperti; turap dibandingkan dengan pendekatan pelestarian magnrove.

Keterlibatan masyarakat pada kegiatan rehabilitasi sangatlah penting dalam mendukung keberlanjutan mangrove. Masyarakat secara keseluruhan perlu mendapat pengertian bahwa hutan mangrove yang akan mereka rehabilitasi akan menjadi milik masyarakat dan untuk masyarakat. Semua proses penanaman, perawatan, penyulaman dan pemeliharaan sampai dewasa dilakukan oleh masyarakat. Melalui mekanisme ini, masyarakat merasa ikut memiliki hutan mangrove. Dari sini akan tergambar, andaikata orang atau kelompok yang bukan anggota masyarakat yang ikut menanam tersebut ingin memotong sebatang mangrove saja, maka mereka tentu akan beramai-ramai untuk mencegah dan mengingatkan.

Ketidakberhasilan dalam kegiatan rehabilitasi diakibatkan beberapa faktor baik dari alam maupun manusia. Untuk mendukung keberhasilan dari kegiatan rehabilitasi, diperlukan upaya yang matang dan sistematis mulai dari perencanaannya (Fisik, biologi dan sosial ekonomi), pelaksanaan dan pengawasan yang melibatkan dari semua elemen baik Pemda maupun masyarakat setempat. 


\section{Dimensi Ekonomi}

Status keberlanjutan untuk dimensi ekonomi pada kategori cukup berkelanjutan. Adapun indikator yang memberikan pengaruh sensitivitas keberlanjutan diantaranya; Pemanfaatan mangrove oleh masyarakat, zonasi mangrove, keuntungan dari pemanfaatan mangrove dan anggaran pemerintah.

Pada dimensi ekonomi, strategi yang diarahkan untuk meningkatkan keberlanjutan yaitu dengan mengembangkan kegiatan ekonomi untuk mengurangi kebergantungan masyarakat akan keberadaan mangrove. Kegiatan ekonomi yang bisa dilakukan berupa pengembangan mata pencaharian alternatif (MPA). Hasil penelitian (Pattimahu, 2010), kebijakan pengelolaan mangrove secara berkelanjutan kedepannya adalah pemberdayaan masyarakat. Kegiatan pemberdaayan masyarakat yang bisa dilakukan dengan peningkatan kemandirian masyarakat lokal terutama masyarakat yang kebergantungannya sangat besar akan mangrove berupa memberikan keterampilan/pelatihan dari instansi terkait untuk pengembangan produk dari mangrove berupa olahan makanan/minuman yang bisa diperjualbelikan dipasaran. Pengembangan sebagai kawasan ekowisata mangrove dan menelusuri kawasan sungai dengan menggunakan perahu. Menurut (Murdiyatmoko, 2012), ekowisata sebagai pariwisata yang dirancang menurut kaidah alami dengan tujuan untuk melestarikan lingkungan, budaya maupun memberi kesempatan kerja bagi masyarakat tempatan dalam meningkatkan taraf hidup. Pertunjukan seni khas Suku Akit juga bisa ditampilkan untuk menambah daya tarik wisatawan nantinya. Kegiatan sosial-budaya dan sosial ekonomi seperti ini jika benar direalisasikan nantinya akan memberikan retribusi yang baik bagi masyarakat lokal juga bagi pemerintah daerah Kabupaten Bengkalis sebagai anggaran yang masuk khusus untuk pengelolaan mangrove.

\section{Dimensi Sosial}

Hasil analisis Rap-Mangrove, dimensi ekonomi berada pada kategori cukup berkelanjutan. Adapun indikator yang memberikan pengaruh pada dimensi ini adalah kearifan lokal. Kearifan lokal merupakan tatanan yang tidak tertulis yang berlaku dikehidupan masyarakat.

Rekomendasi strategi yang disarankan dengan memberikan edukasi dan penyuluhan kepada masyarakat akan pentingya menjaga kelestarian mangrove dengan cara menjaga dan mempertahankan nilai-nilai kearifan lokal yang selama ini menjadi pedoman. Keberadaan kearifan lokal dinilai efektif dalam upaya keselestarian mangrove. Hal ini sesuai pernyataan (Affandy dan Wulandari, 2012), fungsi adanya kearifan lokal untuk keseimbangan antara pemanfaatan sumberdaya, budaya dan alam.

\section{Dimensi Kelembagaan}

Berdasarkan analisis Rap-Mangrove, dimensi kelembagaan berada pada kategori cukup berkelanjutan. Adapun indikator yang berpengaruh pada keberlanjutan adalah ketersediaan dan peran tokoh masyarakat. Strategi yang bisa dilakukan pada dimensi ini dengan Pendekatan yang intensif kepada tokoh masyarakat. Tokoh masyarakat adalah tokoh yang disegani, yang suaranya didengar masyarakat diwilayahnya. Keberadaan tokoh dalam masyarakat desa sangat dibutuhkan. Tokoh masyarakat adalah titik sentral dalam mewujudkan pembangunan yang keberadaannya sangat dibutuhkan dalam pengembangan desa yang lebih baik (Iskandar, Kusnandi, 2017). Peran dari tokoh masyarakat ini sangat baik sebagai fasilitator pemerintah dalam memberikan edukasi dan informasi yang berkaitan dengan isu-isu yang berkembang dilingkungannya terutama upaya-upaya kelestarian pengelolaan mangrove. Untuk itu, diperlukan pendekatan dan komunikasi yang baik dari Pemda bersama tokoh masyarakat.

\section{KESIMPULAN}

Nilai manfaat langsung dari keberdaan mangrove di Desa Jangkang antara lain: Perikanan tangkap, penangkapan udang dan panglong arang. Hasil valuasi ekonomi mangrove di Desa Jangkang menunjukkan sektor penangkapan udang memiliki potensi yang lebih besar dibandingkan dengan sektor lainnya. Nilai ekonomi total udang Rp1.440.000.000/tahun, perikanan tangkap Rp 686.400.000/tahun dan panglong arang $\mathrm{Rp} 447.500 .000 /$ tahun.

Hasil multidimensi nilai indeks dan status keberlanjutan ekosistem mangrove Desa Jangkang diproleh nilai 50.76 dan berada pada kategori kurang berkelanjutan. 


\section{ZONA}

Jurnal Lingkungan

ISSN : 2502-6496 (Print)
Volume 3, No 1, April 2019, p. 34-44 http://zona.pelantarpress.co.id

Strategi keberlanjutan ekosistem mangrove Desa Jangkang pada dimensi ekologi dengan rehabilitasi partisipatif yang melibatkan masyarakat. Pada dimensi ekonomi strategi yang bisa dilakukan dengan pengembangan mata pencaharian alternatif (MPA). Dimensi sosial dengan menerapkan strategi edukasi dan penyuluhan kepada masyarakat Suku Akit untuk mempertahankan nilai kearifan lokal. Dimensi kelembagaan dengan menerapkan strategi pendekatan yang intensif kepada tokoh masyarakat.

\section{DAFTAR PUSTAKA}

Fauzi A. dan Anna, 2005. Permodelan Sumberdaya Perikanan dan Kelautan. Gramedia Pustaka Utama. Jakarta.

Handayani PA. 2016. Pengaruh Penduduk Terhadap Kerusakan Hutan Mangrove di Kampung Lama Kelurahan Dompak Kota Tanjungpinang. 1-1

Kustanti, Asihing. 2011. Manajemen Hutan Mangrove. IPB Press : kampus IPB Taman Kencana Bogor.

Miswadi, R. Firdaus, dan R. Jhonnerie. 2017. "Pemanfaatan Kayu Mangrove Oleh Masyarakat Suku Asli Sungai Liong Pulau Bengkalis”. Dinamika Maritim, Vol. 6 (1): 35-39

Mufid, Sofyan.A. (2010). Ekologi Manusia. PT Remaja Rosdakarya. Bandung.

Osmaleli. 2014. Analisis ekonomi dan kebijakan pengelolaan ekosistem mangrove berkelanjutan di Desa Pabean Udik, Kabupaten Indramayu. Tesis. Bogor.

Pattimahu DV, Kusmana C, Harjomidjojo H, Darusman D. 2010. Analisis Nilai Keberlanjutan Pengelolaan Ekosistem Hutan Mangrove Di Kabupaten Seram Bagian Baraı '. Pascasarjana 33(4) : 239-249.

Presiden RI. 2009. Undang-Undang Nomor. 32 Tahun 2009 tentang Perlindungan dan Pengelolaan Lingkungan Hidup. Sekretariat Negara. Jakarta

Rangkuti, Ahmad Muhtadi. 2017. Ekosistem Pesisir dan Laut Indonesia.Jakarta: Bumi Aksara

Rusdianti, K dan S, Sunito. 2012. Konversi Lahan Hutan Mangrove Serta Upaya Penduduk Lokal Dalam Merehabilitasi Ekosistem Mangrove. Jurnal ISSN : 1978-4333, Vol. 06, No. 01

Sutikno, S, 2014. Analisis Laju Abrasi Abrasi Pantai Pulau Bengkalis Dengan Menggunakan Satelit. Universitas Riau. Pekanbaru. 